\title{
Performance Analysis of Conventional Commercial Banks in Indonesia During the Covid-19 Pandemic (2019-2020)
}

\author{
Fitrina Lestari
}

Nusa Putra University, Sukabumi, Indonesia

*Corresponding author. E-mail: fitrina.lestari@nusaputra.ac.id

\begin{abstract}
To overcome the economic crisis caused by the COVID-19 pandemic, many policies have been made by the Indonesian government, which is expected to stimulate the economy to increase. One way to determine the economic condition is to analyze the quality of banking performance in that country. This research was made to analyze the performance of banking in Indonesia during the COVID-19 pandemic (2019-2020) based on financial ratios, especially Conventional Commercial Banks in BUKU 1 to 4, and also to analyze government policies related to the economy and their impact on banking health conditions during the COVID-19 pandemic (20192020). The methodology for this research is a quantitative method, and the analysis uses descriptive statistics. The data is from Indonesian Banking Statistics (SPI) period 2015-2020 published by OJK. The performance of conventional commercial banks in all bank groups in terms of capital adequacy, liquidity, and credit quality during the 2019-2020 pandemic can still be categorized as a health condition. On the other hand, management and earnings aspects tend to decline due to credit relaxation directed by OJK and the determination of the reference interest rate by Bank Indonesia, which continues to decline. This can be used to note how far banks can survive, especially since the OJK policy regarding credit relaxation is valid until March 2022.
\end{abstract}

Keywords: Covid-19, Banks, Capital Adequacy, Liquidity, Credit Quality, Management, Earning.

\section{INTRODUCTION}

There have been many studies regarding the COVID-19 pandemic and its impact on various sectors of life in society. The first recorded case of Covid-19 appeared in mainland China, and within months, the issues had spread to almost all countries around the world. Due to its fast spread, countries that have experienced a surge in cases of Covid-19 virus infection have made the policy of limiting activities for all community activities.

The existence of restrictions on activities that are pretty long will certainly disrupt a country's economy. A prolonged pandemic will significantly affect the financial system, such as the global unemployment and bankruptcy of large companies, leading to financial fragility (Kimura, 2020). Countries that quickly and effectively make policies related to the Covid-19 pandemic and targeted incentives will recover their economic conditions more quickly.

In Law No. 10 of 1998 , it is stated that Indonesian banking has the primary function of collecting and distributing public funds. The central part aims to support the implementation of national development in improving people's welfare (even distribution of interest, economic growth, and national stability). The increase in the national economy can be assessed from the rise in consumption, investment, and export-import activities. Banking plays a role in these three economic activities. To find out the country's financial condition can be done by analyzing the quality of banking performance.

In Indonesia, the banking industry is supervised by Otoritas Jasa Keuangan (OJK), which has the following functions:

1) Implement a comprehensive and interrelated regulatory and supervisory 
system for all activities in the financial services sector.

2) To regulate and supervise financial service activities in the Banking sector, Capital Market sector, and Non-Bank Financial Industry sector.

The OJK periodically issues Indonesian Banking Statistics, in which data describe the development of banking in Indonesia. The data displayed is financial/transaction data reported to OJK by all conventional commercial banks, Islamic commercial banks, and rural banks every month. These data can be used by the government as a basis for making policies and can also be used by economists or academics in analyzing the economic situation in Indonesia.

\section{LITERATURE REVIEW}

According to RI Law No. 10 of 1998, the bank is a business entity whose activities include collecting funds from the public and distributing them to the community. One of the main objectives is to increase the community's economy. The bank manages three service groups which are managed simultaneously in a professional manner. The three groups are:

1) Funding

2) Distribution of funds (Lending)

3) Provision of other services (Service)

In POJK No 6/POJK.03/2016, there are four groups of banks categorized based on their core capital; commonly known as BUKU (Bank Umum Kegiatan Usaha/ Commercial Bank Business Activities); namely:

Table 1. Bank group division based on core capital owned

\begin{tabular}{|c|c|}
\hline & Core Capital (Trillion Rp) \\
\hline Buku 1 & $\leq 1$ \\
\hline Buku 2 & $\geq 1$ s.d. $\leq 5$ \\
\hline Buku 3 & $\geq 5$ s.d. $\leq 30$ \\
\hline Buku 4 & $\geq 30$ \\
\hline
\end{tabular}

The category of banks based on this BUKU will then become the basis of business activities for banks operating in Indonesia. During carrying out their business activities, Banks will be regulated and supervised to always be in good health.

The government issued a regulation regarding assessing the soundness of commercial banks as outlined in PBI Number 13/1/PBI/2011. In this regulation, banks must individually set the bank's stability using a risk approach. The assessment of the bank's soundness includes a risk profile, good corporate governance, earnings, and capital. The measurement of the bank's health which provides for these four things is generally carried out using CAMEL analysis. Camel analysis can be described as follows:

1) Capital, namely the capital owned by the bank. The assessment uses the capital adequacy ratio (CAR) method, also known as the minimum capital adequacy ratio, by comparing wealth to risk-weighted assets (RWA).

2) Assets, namely the quality of assets/assets owned by the bank. The assessment is done by measuring two kinds of ratios, namely the ratio of earning assets and the ratio of allowance for losses on making assets to classified earning assets.

3) The assessment is based on the overall management, namely capital management, asset management, profitability management, liquidity management, and general management.

4) Earnings, namely Profitability or the ability of a Bank to create profit. The assessment is based on ROA (return on assets) or the ratio of profit to total assets and BOPO (percentage of operating expenses to operating income).

5) Liquidity or liquidity, the assessment is based on two ratios: the percentage of total net liabilities (call money) compared to current assets and the balance between credit and funds received by the bank.

\section{RESEARCH METHODS}

The research was conducted using quantitative methods and descriptive statistical analysis. According to Sugiyono (2015), descriptive statistics are statistical analyses to analyze data by describing or describing the data that has been collected as it is without intending to make generally accepted conclusions. The data used during the research is data from SPI (Indonesian Banking Statistics) for the 2015-2020 period published by OJK.

\section{RESULTS AND DISCUSSION}

To improve the Indonesian economy during the COVID-19 pandemic, OJK made policy Number 11 /POJK.03/2020, which policy Number 48 /POJK later amended.03/2020 valid until March 2022. Policies aimed at real sector businesses directly impact banking, including capital relaxation and credit management policies. The author will analyze these policies using several measuring tools 
in the CAMEL method, which functions to assess the bank's overall soundness, measure the bank's performance, and detect problems that pose a risk to the smooth operation bank.

In POJK No. 11/POJK.03/2016, it is stated that banks are required to meet the minimum capital requirement as regulated as follows:

Table 2. Minimum capital requirement based on the risk profile

\begin{tabular}{|c|c|}
\hline & $\begin{array}{c}\text { Risk Weighted } \\
\text { Asset }\end{array}$ \\
\hline Risk Profile Rating 1 & $8 \%$ \\
\hline Risk Profile Rating 2 & $9 \%$ \\
\hline Risk Profile Rating 3 & $10 \%$ \\
\hline Risk Profile Rating 4 or 5 & $11 \%$ \\
\hline
\end{tabular}

To ensure that banks can still meet the level of capital adequacy, the OJK has made a relaxation policy as follows:

1) Eliminating the obligation to fulfill the Capital Conservation Buffer in the capital component for BUKU 3 and BUKU 4 banks of $2.5 \%$ of RWA until March 31, 2021.

2) The obligation to fulfill LCR (Liquidity Coverage Ratio) and NSFR (Net Stable Funding Ratio) for BUKU 3, BUKU 4, and foreign banks must be maintained at a minimum of $85 \%$ until March 31, 2021. Banks must make a follow-up plan to return the fulfillment of LCR and NSFR to $100 \%$ no later than April 30, 2021.

3) The obligation to provide education funds for 2020 can be less than $5 \%$ of the HR budget.

4) The implementation of Basel III Reforms standards in Indonesia, including RWA calculation for operational risk, credit risk, market risk, and CVA (Credit Valuation Adjustment), was postponed to January 1, 2023.

The average Indonesian banking capital ratio in $2015-2020$ can still be categorized as healthy (> $8 \%$ ). Except for the group of banks in BUKU 4, which experienced a slight decline, the banks in BUKU 1 to 3 increased their capital adequacy ratio. According to Kashmir (2017), this increase in the capital adequacy ratio can be obtained from many posts, including stock premium, general reserves, current year profit, retained earnings, fixed asset revaluation reserves, allowance for the write-off of productive assets, or credit capital.

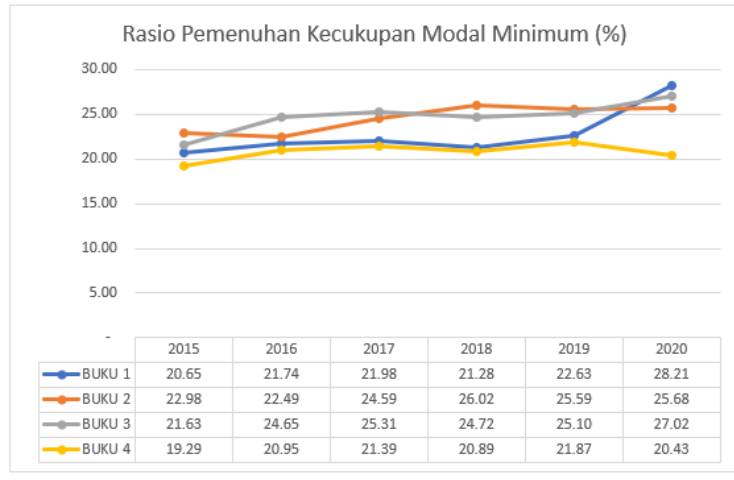

Figure 1. Minimum Capital Adequacy Ratio

OJK's policies, which appear to be devoted to groups of banks in BUKU 3 and 4, have a reasonably good effect on the capital adequacy ratio in all bank groups due to the average position of the bank's capital adequacy ratio increasing and not decreasing significantly.

In line with policies related to capital which have a significant effect on banks, credit relaxation policies also significantly affect bank soundness ratios. The largest category of bank assets is credit, credit is relatively illiquid compared to the securities market and has a greater risk of default and higher information costs.

In POJK No. 40/POJK.03/2019, concerning assessing the quality of commercial bank assets, it is stated that credit quality is set to be current, with particular attention, substandard, doubtful, and wrong. The pandemic situation is very influential on the business world and the economy in Indonesia. This is, of course, also related to the quality of credit in Indonesian banks. Therefore, the OJK makes policies so that the economy can run and bank credit quality remains within safe limits. These policies include:

1) Implement one pillar payments, namely the accuracy of paying principal and interest for a credit limit of Rp10 billion, valid until March 31, 2022.

2) After being restructured, the credit quality affected by Covid-19 is determined to be Current, which is valid until March 31, 2022.

3) New credit additions can be given to Covid19 restructuring debtors by determining/recording credit quality separately from previously granted credit quality (the uniform classification principle does not apply).

4) The Covid-19 credit restructuring period is valid until March 31, 2022, adjusted to risk management at each bank. If the credit 
restructuring exceeds the stipulated period, the debtor's credit quality is determined by referring to the POJK on Asset Quality.

5) To monitor the development of Covid-19 restructuring loans, all restructuring loans are reported by adding the statement "COVID19" until the loan is paid off, even though it has passed March 31, 2022. Covid-19 restructuring loans can also be excluded from calculating low-quality credit assets (Loan at Risk) in the assessment Bank Health Level.

6) Based on ownership, the quality assessment of AYDA (foreclosed assets) can be suspended until March 31, 2021. After that, the AYDA quality assessment again refers to the provisions for assessing the quality of bank assets based on the period of ownership by the bank since the AYDA is executed without taking into account the relaxation period.

The above policies proved effective in maintaining good credit quality, as illustrated in the chart below, which shows that the percentage of productive assets in the current account category is relatively stable except for BUKU 1, which experienced a decline in 2020. From its launch in March 2020 until the end of December 2020, this banking credit restructuring program had reached a value of more than 971 trillion rupiahs which was given to 7.6 million debtors or about $18 \%$ of the total credit issued by banks. This amount is claimed to be the most significant restructuring in the history of banking in Indonesia. However, the government hopes that this restructuring will be able to make the business world rise and the wheels of the Indonesian economy continue to grow.

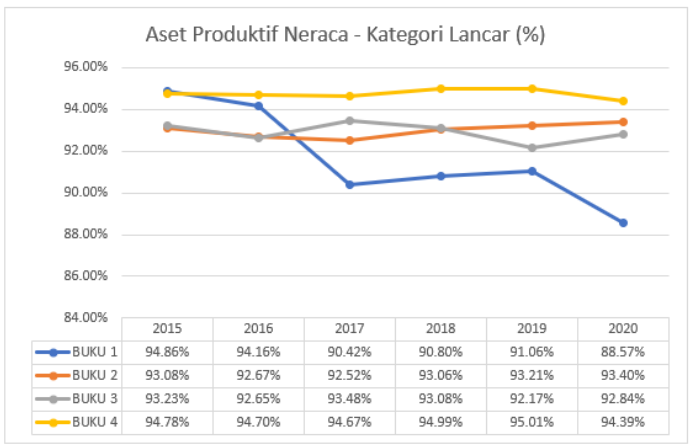

Figure 2. Earning Assets Tables and Charts Current Category

And if you look at the liquidity ratio, namely the Loan to Deposit Ratio (LDR), the value can also be considered stable and in the healthy category from 2015 - 2020 except for the BUKU 3 bank group, which is in the reasonably healthy category. The liquidity aspect can be defined as the bank's ability to pay its debts, especially short-term debt. Liquidity assessment is calculated by comparing the net liabilities to current assets and credit ratios to funds received by the bank.

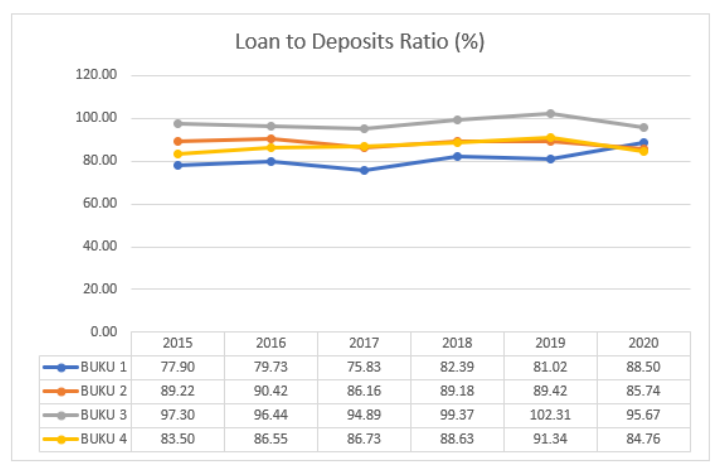

Figure 3. Total Credit Ratio compared to total third party funds

The higher the Loan to Deposit Ratio value indicates that the loans issued are large and the level of liquidity the bank owns is lower, the smaller the LDR value suggests that the bank is increasingly liquid. The soundness of a bank in terms of liquidity is based on the following LDR value range.

- $\quad 94.75 \%$ : Bank is healthy

- $\quad>94.75 \%-98.50 \%$ : Bank is quite healthy

- $\quad>98.50 \%-102.25 \%$ : Bank is not healthy

- $102.25 \%$ : Bank is not healthy

Banks must provide credit and investment carefully to earn interest rates high enough to cover costs and generate profits, not least during a pandemic like the current one. The bank's income is mainly generated from investment and credit interest, revenue from services provided such as credit cards, purchases/payments, and foreign currency exchange transactions. Meanwhile, fees to the bank are usually paid for interest on deposits, service fees, operational costs, and much more. Net Interest Margin Ratio (NIM) is the ratio of the valuation of interest income earned compared to total assets.

$$
\begin{aligned}
& \mathrm{NIM}=\frac{\text { Net Interest Income }}{\text { Productive Asset }} \times 100 \% \\
& \mathrm{ROA}=\frac{\text { Profit After Tax }}{\text { Tottal Asset }}
\end{aligned}
$$




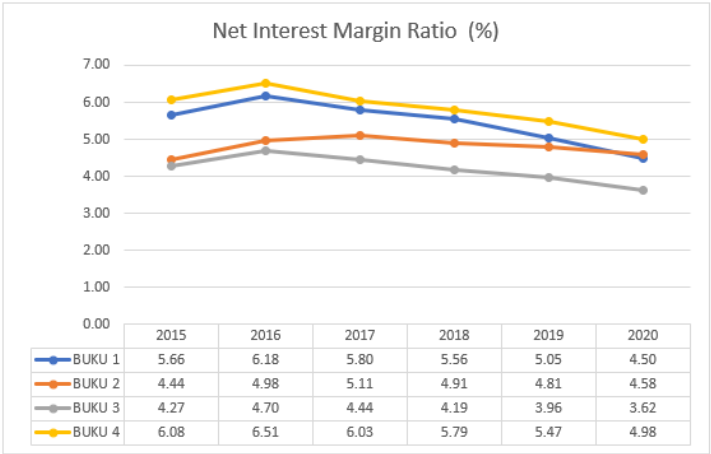

Figure 4. Net Interest Margin Ratio

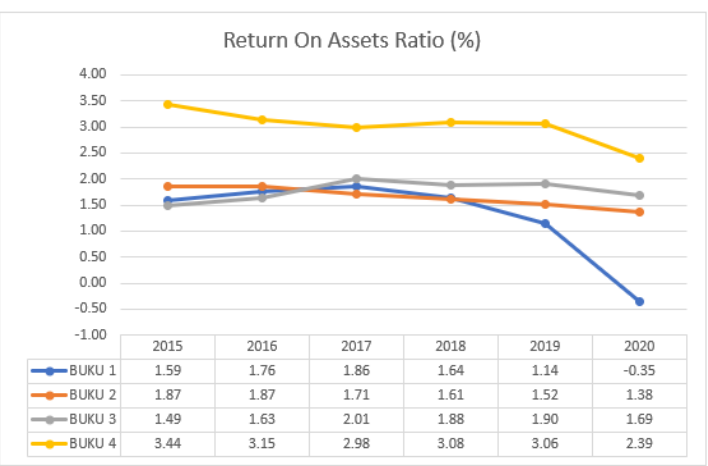

Figure 5. Return on Assets Ratio

Banks with good performance can be seen from their ability to earn income in profits. The greater the profit (ROA) shows the bank's performance is getting better and its financial condition is healthy. In contrast to the capital adequacy ratio, credit quality ratio, and LDR value which tend to be stable, the NIM and ROA ratios tend to decrease during the pandemic. One of the reasons for the decline in NIM and ROA is the relaxation of credit policies issued by the OJK, thereby reducing income from loan interest.

In addition to influencing the NIM and ROA values, OJK policies also impact the increase in the BOPO Ratio (operational costs to the bank's operating income). On the other hand, this credit restructuring is beneficial because the credit quality is good so that banks do not need to reserve funds due to bad loans. Still, on the other hand, this restructuring reduces interest income. If we look at the chart above, the value of productive assets in the current category tends to be stable. The BOPO value can be concluded from decreasing interest income and increasing other operating costs. The BOPO ratio is a ratio that shows the bank's performance in utilizing all of its production factors efficiently and effectively. A large BOPO ratio means that the bank is not efficient and effective in managing its operational costs.

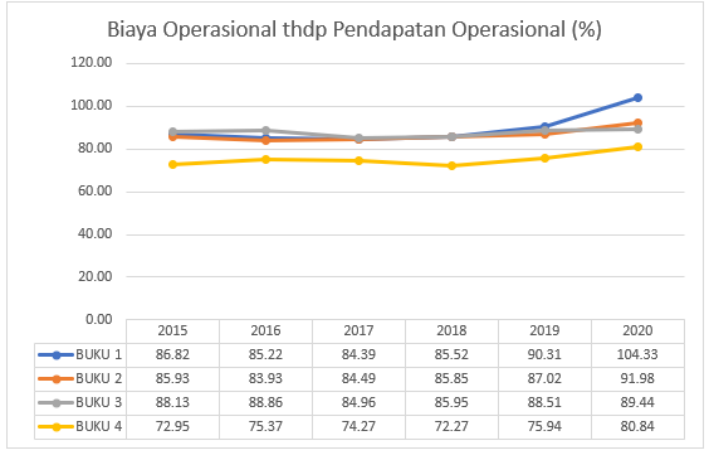

Figure 6. The ratio of Operating Expenses to Operating Income

The decline in the benchmark interest rate issued by BI is in line with improving the wheels of the economy in Indonesia, which has not shown any improvement. Low-interest rates are set because of low inflation, and vice versa. If inflation shows signs of increasing, then interest rates will also increase. It is hoped that with low-interest rates, people will withdraw their funds from banks and expand their business/consumption.

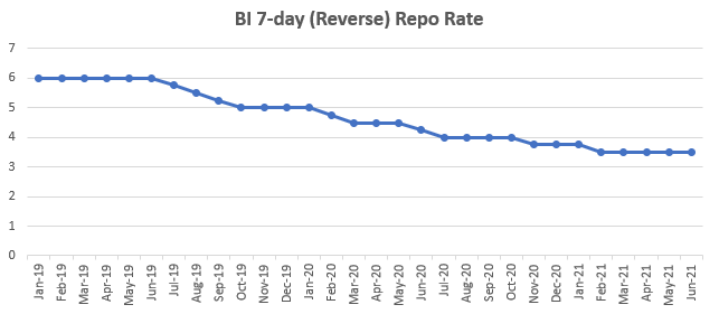

Figure 7. BI 7-day Interest Rate (Reverse)

\section{CONCLUSION}

1) The performance of conventional commercial banks in all bank groups in terms of capital adequacy, liquidity, and credit quality during the 2019-2020 pandemic can still be categorized as good/healthy. On the other hand, management and earnings (earnings) tend to decline due to the relaxation of credit directed by the OJK and the determination of the reference interest rate from BI, which continues to decline.

2) Policies related to mitigating the impact of the COVID-19 pandemic issued by the government on banking performance have had a reasonably good effect, as seen from financial banking ratios, which are still in the healthy category. However, it is also necessary to pay attention to the impact on the ability of banks to generate declining profits and increase operational costs. This can be 
used to note the extent to which banks can survive with the current conditions and policies, especially since the OJK policy regarding credit relaxation is valid until March 2022.

This pandemic has pushed banks to start changing the way they work to be more effective and efficient and adapt to changes in post-pandemic conditions (new standard). Banks can apply several strategies in dealing with an unstable economy, namely:

1) Maintaining quality relationships with customers, conducting credit risk assessments based on the personal information of prospective creditors. The best way for banks to obtain information and creditor needs is to maintain long-term relationships with these creditors (Hubbard, 2012).

2) Increase low-cost fundraising (CASA) to reduce interest expense.

3) Digitalization of all banking aspects, starting from strategic, operational, and product and service sales, to reduce operating costs and speed up the process.

4) Increase non-interest income.

\section{REFERENCES}

[1] P. Watts, Corporate social responsibility: meeting changing expectations. World Business Council for Sustainable Development, 1998.

[2] S. J. Brammer, C. Brooks, and S. Pavelin, "Corporate Social Performance and Stock Returns: UK Evidence from Disaggregate Measures," SSRN Electron. J., no. December 2019, 2011, doi: 10.2139/ssrn.739587.

[3] B. Arya and G. Zhang, "Institutional reforms and investor reactions to CSR announcements: Evidence from an emerging economy," J. Manag. Stud., vol. 46, no. 7, pp. 1089-1112, 2009, doi: 10.1111/j.14676486.2009.00836.x.

[4] I. Mahbubah and S. Subaida, "Corporate Social Responsibility: Building Corporate Image of Pt Bank Rakyat Indonesia, Tbk in Sumenep District," Int. Jt. Conf. ..., pp. 160163, 2020, [Online]. Available: https://journal.trunojoyo.ac.id/ijcst/article/v iew/8225.

[5] M. Jihadi, E. Vilantika, S. M. Hashemi, Z. Arifin, Y. Bachtiar, and F. Sholichah, "The
Effect of Liquidity, Leverage, and Profitability on Firm Value: Empirical Evidence from Indonesia," J. Asian Financ. Econ. Bus., vol. 8, no. 3, pp. 423-431, 2021, doi: 10.13106/jafeb.2021.vol8.no3.0423.

[6] K. H. Titisari, K. Ratnawati, and N. K. Indrawati, "Mediation Role of Corporate Social Responsibility on Corporate Governance and Firm Value: Evidence from Indonesia Firms," IOSR J. Econ. Financ., vol. 9, no. 5, pp. 71-77, 2018, doi: 10.9790/5933-0905017177.

[7] A. Goss and G. S. Roberts, "The impact of corporate social responsibility on the cost of bank loans," J. Bank. Financ., vol. 35, no. 7, pp. 1794-1810, 2011, doi: 10.1016/j.jbankfin.2010.12.002.

[8] T. kasbi Ridho, "CSR In Indonesia: Company`s Perception And Implementation," EUrASEANs J. Glob. socio-economic Dyn., vol. 3, no. 4, pp. 6874, 2017.

[9] S. A. W. and S. B. Graves, "The Corporate Social Performance-Financial Performance Link," Strateg. Manag. J., vol. 18, no. 4, pp. 303-319, 1997, [Online]. Available: https://www.jstor.org/stable/3088143 .

[10] Y. K. F. Adrian Himawan Santoso, "The Association Between Corporate Social Responsibility And Corporate Financial Performance," Issues Soc. Environ. Account., vol. 8, no. 2, pp. 82-103, 2014, doi: dx.doi.org/10.22164/isea.v8i2.86.

[11] M. Masodah and M. Permanasari, "Bukti Empiris Pengaruh Corporate Social Responsibility Terhadap Tingkat Profitabilitas, Besaran Pajak Penghasilan, Dan Biaya Operasi Pada Perusahaan Yang Terdaftar Di Bursa Efek Indonesia," J. Ilm. Ekon. Bisnis, 2012, doi: 10.35760/eb. 